\title{
\#I ENVY, THEREFORE, I BUY! \#: THE ROLE OF CELEBGRAM TRUSTWORTHINESS AND PARA-SOCIAL INTERACTIONS IN CONSUMER PURCHASE INTENTION
}

\author{
Purwanto Purwanto \\ Faculty of Economics and Business, W. R. Supratman University of Surabaya, Indonesia \\ Email: cakpo3r@gmail.com
}

\begin{abstract}
Businessmen's marketing strategies that take advantage of the fame of celebgrams as influencers are incredibly appropriate in the social media era. The present study deals with the dynamics of celebgram trustworthiness and social interaction with their followers in relation to possession envy and consumer purchase intention. To test the proposed model, the researchers collected data from 181 respondents in Indonesia through an online survey and analyzed it using the Smart PLS. The results of the present study showed that celebgram trustworthiness had no positive effect on possession envy but it had a positive effect on consumer purchase intention. Furthermore, para-social interactions had a positive effect on possession envy and consumer purchase intention and possession envy had a positive effect on consumer purchase intention. The present study provides a theoretical contribution to the literature on retail and consumer services and offers managerial implications for instafamous-based marketing.
\end{abstract}

Keywords: Celebgram trustworthiness, para-social interactions, possession envy, purchase intention.

\section{Introduction}

Numerous well-known clothing brands in Indonesia take advantage of the fame of celebgrams as influencers to promote their products to consumers. For example, the clothing brand Riotous Bell that partners with such Instagram influencers as @kasmaranindonesia can reach more than five million viewers (Pratnyawan \& Prisilia, 2018). The presence of Instagram is capable of giving birth to millions of new fashionistas who not only collaborate in terms of brands but also potentially launch their own product lines (Adler, 2016; Arora, Bansal, Kandpal, Aswani, \& Dwivedi, 2019).

According to Indvik (2016), the top fashion bloggers played an important role as influencers via Instagram since they had millions of followers and actively engaged with consumers on a regular basis, and served to create deep brand awareness ultimately influencing purchasing decisions (Loureiro, Costa, \& Panchapakesan, 2017). This is proven by the Report for Influencer Marketing in Asia (AnyMind, 2020) that throughout March 2020 more than 98 million posts on Instagram as User-Generated Content (UGC) with the hashtag \#Fashionista were capable of increasing sales more of $42 \%$. The fame of celebgrams and UGC creates a new format for marketing strategies under the name of influencers who collaborate with brands to promote their products (de Veirman, Cauberghe, \& Hudders, 2017). Therefore, business people and brands are increasingly interested in taking advantage of famous figures born from UGC with credibility as brand ambassadors on social media, despite the fact that they are not famous actresses and actors or athletes.

According to Gallagher, Watt, Weaver, and Murphy (2017), investment for promotion via social media may reach US\$ 10 billion in 2022 with $38 \%$ growth per year specifically in fashion, beauty and tourism, while research related to the credible influencer marketing believed to influence consumers remains scarce (de Veirman et al., 2017; Jin \& Ryu, 2020; Sokolova \& Kefi 2020). Using influencer services should also consider its credibility in order to be trusted by consumers. Thus, influencers should have more insight into their daily attitudes and behaviors when working with brands in order to motivate their followers (Sokolova \& Kefi, 2020).

Previous literature has focused a lot on celebrities well-known on TV and mainstream media (Ford, 2018). However, well-known celebrities can only be used by large companies and well-known brands that can afford to pay high prices on a national and even international scale (Abidin, 2016). Meanwhile, many celebrities are currently viral due to their creative contents, have many followers and are relatively inexpensive, leading many marketers to eye them (de Veirman et al., 2017) to promote their products and brands. This is considered more potential and unconventional than advertisements (de Vries, Gensler, \& Leeflang, 2012), despite the fact that the quality of the contents look less professional and tend to contain promotions only (Hautz, Füller, Hutter, \& Thürridl, 2014; Müller, Mattke, \& Maier, 2018). The purpose of the present study was to analyze the effect of celebgram trustworthiness as content creators and para-social interactions 
on the emotion of possession envy and purchase intention. Despite the great effect of the presence of celebgrams on purchasing decisions, there are scant studies on the success factors of Instagram celebritybased marketing, such as celebgram trustworthiness and social interactions (Jin \& Ryu, 2020). Celebgram trustworthiness depends on authority, credibility and social attractiveness (Kelman, 1958; Rogers \& Bhowmik, 1970). However, a celebgram who has just gone viral due to his or her interesting content but has not yet received recognition and trust from followers constitutes a challenge for producers who want to use his or her services as marketing influencers. The options for marketers are to use established influencers with many followers or to use influencers who have just gone viral but have not had credibility and trustworthiness among consumers.

Previous studies stated that a lot of contents created by celebgrams merely looked for popularity without paying attention to ethics and without decent sentences, which seemed to be sensational, such as displaying sensual photos both in selfies and groups (Jin \& Ryu 2020). Other studies emphasized the role of bloggers in persuasive cues through authority as public figures who are considered capable of influencing consumers (Sokolova \& Kefi, 2020). Despite the influence of celebgrams' authority, no further studies have been done regarding whether or not the person concerned can be trusted in terms of his or her consistency of words and actions. Authority born of contents on YouTube and other social media is only contemporary since it is not accompanied by a trustworthy attitude (de Veirman et al., 2017). Therefore, the aspect of trustworthiness is important in order to build a halo effect for influencers to seek fame with a strong public identity and resources to promote themselves on an established celebrity scale and to increase social interaction with their followers.

Meanwhile, interactivity in e-commerce is the best way to build relationships with customers through a two-way relationship between buyers and sellers (Yoo, Lee, \& Park, 2010). Celebgrams' social interactions on social media have not been fully studied in the literature of Instagram-based marketing capable of arousing consumer emotions in increasing purchase intention. Previous literature argues that trustworthiness is related to honesty, whereas a good intention reflects caring (Petty \& Wegener, 1998). Thus, taking advantage of a celebgram's fame and care capable of building social attitudes through interaction with followers can fill empirical gaps and provide practical insight into effective instafame-based marketing strategies on social media.

The rise of promotions via the Instagram makes consumers happy to follow and form Para-SocialInteractions (PSI) with celebgrams by making illusory face-to-face meeting via social media. Therefore, what the celebgrams do and use through showcases on the Instagram arouses envy. In the end, consumers decide to buy the products and brands they use (Milovic, 2014). Consumers are envious to have it, as a dimension of materialism (Belk, 1984), which is generated by celebgrams through the products or brands they use (Belk, 2008; McFerran, Aquino, \& Tracy, 2014). Especially with the presence of social media, many celebgrams often show off their glamorous lifestyle, encouraging many followers to make social comparisons and leading to materialistic jealousy and compulsive obsessiveness (Chae, 2018; Jin, Ryu, \& Muqaddam, 2018). The new way of interaction between brands and consumers on social media constitutes a challenge for marketers to use social media strategically and create consumer-attracting contents which are in turn capable of creating customer value (Schulze, Scholer, \& Skiera, 2015).

Consumer interactions in marketing via social media occur when there are responses to contents created by celebgrams and encourage brand or product awareness which in turn influences consumer purchasing decisions (Ashley \& Tuten, 2015; Kim \& Johnson, 2016). This phenomenon makes interaction in social media a central role of e-WOM and as a medium for brand communication (Muller \& Christandl, 2019; Roma \& Aloini, 2019). Thus, celebgrams' social interactions provide a theoretical and practical basis for brand interactions, celebgram trustworthiness, and brand trustworthiness in increasing consumer purchase intention.

The final section will discuss the literature and research hypotheses, explain the research methodology, present the results empirically, and discuss the results, describe the conclusions, theoretical and practical implications, as well as the limitations and direction of future research.

\section{Effects of Celebgram Trustworthiness}

The presence of celebgrams and the way they influence their followers depend on authority, credibility and social attractiveness (Kelman, 1958). Authority is related to the position of a celebgram within a social structure who is believed to be a public figure. A celebgram has an authority to mobilize their followers in activities that are beneficial both personally and in groups (Kelman, 1958; Sokolova \& Kefi, 2020). Credibility describes how reliable and dependable a celebgram's content source is (Rogers \& Bhowmik, 1970). A celebgram's credibility is shown by the quality of their communication with the audience. The credibility of communication affects the audience through daily behavior by means of the contents created (Kelman, 1958). The main factor of 
credibility is knowledge, experience, trustworthiness and goodwill possessed by the source (McCroskey \& Teven, 1999; Sokolova \& Kefi, 2020). Trustworthiness is related to honesty, whereas a good intention reflects caring for followers. In general, celebgrams can be considered trustworthy, must be attractive, and are considered experts, so that they are capable of influencing their follower attitudes and behavior which in turn affect purchase intention (Petty \& Wegener, 1998; Gunawan \& Huarng, 2015). Social attractiveness derives from a figure's capability to change their followers through communication (Sharma, 1990). Perceived social attractiveness can be cues for decision making (Chaiken, 1979). According to Kelman (1958), members of the audience will follow their idolized figures in order to be similar or resemblant. Millennials are considered social media users who are vulnerable to being influenced by fashion developments led by celebgrams.

Previous literature argues that celebgrams' lifestyle and personality constitute the mecca for fashion development (Boon, 2001; Peter, 2004). The social cognitive theory shows that people are more easily influenced by figures considered similar to them (Bandura, 2009). For example, millennials are more likely to buy products endorsed by someone who matches their self-image (Sukhdial, Aiken, \& Kahle, 2002; Sokolova \& Kefi, 2019). In terms of social structure, celebgrams have a direct effect on their followers (Gass, 2015; Jin \& Ryu, 2020). Furthermore, an influencer can be considered to have a higher social status, despite their inability to directly reward or punish followers who have or have not bought the products they endorse (Sokolova \& Kefi, 2020). However, what is worn by celebgrams can trigger envy in followers (Belk, 2008). Furthermore, envy constitutes a dimension of materialism (Belk, 2008; McFerran et al., 2014) generated when celebgrams wear certain products and brands.

Such influencers as Febby Rastanti (@febbyrastanti) and Andra Alodita (@alodita) post various types of photos, both selfies and groups, with glamorous and attractive brands to promote certain brands. Glamorous photos of celebgrams posted on the Instagram tend to be more powerful in triggering follower envy (Jin \& Muqaddam, 2018; Jin et al., 2018). Furthermore, Jin et al. (2018) and Jin and Ryu (2020) state that celebgram trustworthiness as seen in Instagram photos is stronger narcissistically in generating consumer jealousy or envy and capable of leading to envy which in turn increases purchase intention (Lin, 2018).

Previous studies have suggested that the type of contents and tone of voice can increase perceived trust in celebgrams and brands. A loud and clear voice makes followers understand the content of the conversation (Kelleher, 2009; Beukeboom, Kerkhof \& de Vries, 2015) and can influence perceived trustworthiness and purchase intention on social media (Barcelos, Dantas \& Senecal, 2018), consequently increasing brand evaluation (Beukeboom et al., 2015), including brand trust, brand satisfaction, and brand commitment (Kelleher \& Miller, 2006). A celebgram as a brand identity serves to sell products through follower endorse and the celebgram's personality touch and encourages consumer consumption through various communities (Holmes \& Redmond, 2014; Centeno \& Wang, 2017). Previous literature also states that celebgrams are considered more believed to evoke envy and PSI which are stronger than mainstream media celebrities (Jin, Muqaddam, \& Ryu, 2019).

$H_{1}$ : Celebgrams' trustworthiness has a positive effect on envy to follow the celebgram as their idol.

$H_{3}$ : Celebgram trustworthiness has a positive effect on consumer purchase intention.

\section{Effects of Para-Social Interactions}

The para-social interaction (PSI) theory is defined as a form of one-way relationship between actors and non-dialectical followers controlled by the media (Horton \& Wohl, 1956) and describes interpersonal intimacy as if it were real (Dibble, Hartmann, \& Rosaen, 1995). Relationships are built naturally and the parties are unaware that the relationships actually affect each other (Kelman, 1958). Kelman further stated that PSI refers to the response that a person gives to a celebgram on social media as if the celebgram is at the same room as the consumer.

Previous literature suggested that women have para-social interactions to express their desire to resemble the celebrity they idolize (Greenwood, Pietromonaco, \& Long, 2008; Sokolova \& Kefi, 2020). In some ways, this can be similar to a celebgram in terms of the relationship between social media users and influencers. For example, celebgrams using social media make posts related to the products and brands they wear so that they can influence their followers' emotions such as envy to possess what they wear (McFerran et al., 2014; Jin \& Ryu, 2020).

Previous empirical studies suggest that followers form a community and share values, beliefs, and interests (Nambisan \& Watt, 2011). Therefore, the two-way relationship between the community and the celebgram seems to be real, even though it is only an illusion that occurs in cyberspace (Labrecque, 2014; Lee \& Watkins, 2016). Kim, Ko, and Kim (2015) found that the use of social networks was positively related to para-social interactions. For example, young women participate in all celebgram activities starting from their habits, lifestyle, to the fashion they wear, which may arouse envy (Djafarova \& Rushworth, 
2017). Lee and Watkins (2016) argued that social interactions between celebgrams and followers had a positive effect on the emotion of possession envy to buy luxury brands and to aspire similarities to the celebgrams on social media. Other literature also states that PSI is positively related to purchase intention because of followers' envy and self-esteem (Chung \& Cho, 2017; Hwang \& Zhang, 2018). Women show a more intimate PSI and express a stronger desire to imitate their idols (Greenwood et al., 2008; Sokolova $\&$ Kefi, 2020). The envious attitude to imitate their idols is a social comparison behavior with the aim of having conformity to social standards (Wiedemann, Hennigs, \& Siebels, 2009).

Social comparison theory plays an important role in the materialism of values and compulsive buying (Islam, Sheikh, Hameed, Khan, \& Azam, 2018). Compulsive buying is repetitive purchase due to emotional factors (one of them being envy) and hedonic factors and luxury brands (Ridgway, KukarKinney, \& Monroe, 2008; Horvath \& Adiguzel, 2018). Hedonic values are crucial to describe the luxury of a brand in consumption that provides satisfaction and sensory enjoyment through experiences with luxury products (Purwanto \& Kuswandi, 2017). The luxury brands worn by celebgrams are longer and elastic in delivering the promise of pleasure and emotional effects (Hagtvedt \& Patrick, 2009). The celebgrams' aesthetical posts of luxury brands in the form of photos on the Instagram platform evoke consumers' hedonistic sensation and emotional appeal (possession envy) (Ajitha \& Sivakumar, 2017; Sokolova \& Kefi, 2020).

$\mathrm{H}_{2}$ : Social interactions have a positive effect on possession envy of wearing brands worn by their idols.

$H_{4}$ : Para-social interactions have a positive effect on consumer purchase intention.

\section{Possession Envy}

Jealousy or envy is an interpersonal attitude of individuals that involves a dislike and ill will towards other individuals in terms of happiness, success, reputation or possession of whatever desired (Belk, 1984). The envy of a materialist individual is directed to other people's possession of goods. It is oriented towards other individuals' possession of something. As with possessiveness and non-generosity, envy is understood here as a general trait, rather than a specific attitude towards individuals. Envious individuals expect to possess what their idols wear (Jin \& Ryu, 2020). Negatively envious individuals hate those who possess the property they want and feel personally despised by other individuals who possess the property they want, especially when those other individuals are seen as less worthy of possessing the property (Belk, 2008; McFerran et al., 2014). However, in the present study, the envy was one that positively evoked consumers' emotions to imitate or possess the goods used by celebgrams. Possession envy against celebgrams derived from the posted narcissistic photos, both in selfies and groups, which could portray sociability and popularity (Jin \& Muqaddam, 2018).

Moreover, the posts of photos of wearing branded clothes seem glamorous and cause a stronger possession envy (Jin et al., 2018). Furthermore, Jin and Ryu (2020) stated that the types of celebgrams' post created consumer envy which in turn increased purchase intention. Previous literature also argued that PSI with celebrities through social media increases envy (Chung \& Cho, 2017).

Theoretically, envy has a positive relationship with consumer purchase intention and tends to compete evolutionarily either intraexually or intersexually (Buunk \& Massar, 2012). In the context of celebgram influencer-based marketing, narcissistic and glamorous photos can evoke envy and in turn increase consumer purchase intention (Milovic, 2014; Lin, 2018). Based on these theoretical and empirical reasons, the following hypothesis is proposed:

$H_{5}$ : Possession envy has a positive effect on consumer purchase intention.

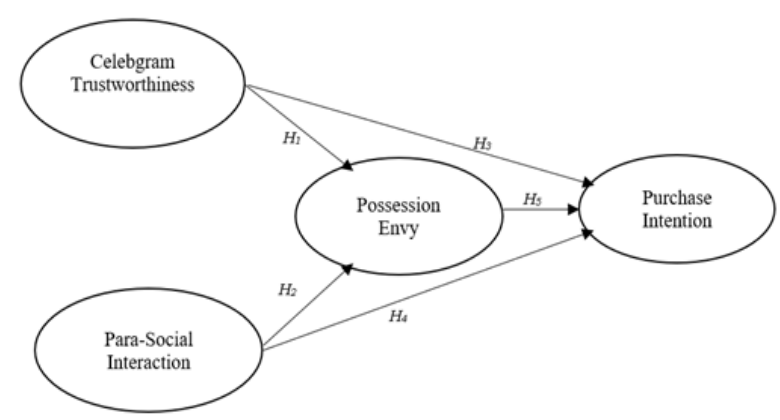

Figure 1. The proposed model

\section{Research Method}

\section{Sample and Data Collection}

The sample of the present study consisted of 181 respondents who were Instagram users who had stated that they were followers of their idolized celebgrams in the purchasing decision-making process. Data were collected from 300 respondents using questionnaires distributed via email and WhatsApp, of which 181 respondents were declared to be fully eligible (response rate of $60.33 \%$ ). 
The characteristics of respondents included those people who have transacted online and their decisions were influenced by the posts or activities of celebgrams as marketing influencers on social media. Of those respondents, 99 were women and were 82 men, with an average age of 30.101 years (ranging from 18 to 44 years representing Generations $\mathrm{Y}, \mathrm{Z}$, and $\mathrm{X}, \mathrm{SD}=$ 5.472). Finally, the majority of consumers, or $38.121 \%$, had an undergraduate/diploma education, $16.022 \%$ master's degrees, $3.867 \%$ doctoral degrees and $6.077 \%$ upper secondary education. In detail, the characteristics of the respondents are shown in Table 1.

Table 1

Sample Characteristics $(N=181)$

\begin{tabular}{|c|c|c|c|c|}
\hline & Frequency & Percent & Mean & $\begin{array}{l}\text { Standard } \\
\text { Deviation }\end{array}$ \\
\hline Age & & & 30.101 & 5.472 \\
\hline \multicolumn{5}{|l|}{ Gender } \\
\hline Male & 82 & 45.303 & & \\
\hline Female & 99 & 54.696 & & \\
\hline \multicolumn{5}{|l|}{ Education } \\
\hline High school or lower & 11 & 6.077 & & \\
\hline Vocational/technology & 20 & 11.049 & & \\
\hline Some college & 27 & 14.917 & & \\
\hline Bachelor's degree & 69 & 38.121 & & \\
\hline Master's degree & 29 & 16.022 & & \\
\hline Doctoral Degree & 7 & 3.867 & & \\
\hline
\end{tabular}

\section{Instrument}

The present study used a questionnaire designed online with Google Form for data collection. The survey was tested to 20 respondents online to detect possible flaws in the design and the instrument. This was important to avoid negative consequences for survey activities such as ambiguity, confusion, and offensive questions (Cooper \& Schindler, 2013). Based on consumer comments and suggestions, the researchers improved several items and entered the Google Form again. Responses were recorded using a Likert scale of 1 for strongly disagree to 7 for strongly agree.

\section{Measurement}

Based on several previous studies, we developed 13 statement instruments (Table 2). First, the measurement of celebgram trustworthiness consisted of four items adopted from Beukeboom et al. (2015), (Ford, 2018), and Sokolova and Kefi (2020) with a Likert scale of 1 for strongly disagree to 7 for strongly agree. Second, para-social interaction consisted of four items adopted from Jin and Ryu (2020), Ajitha and Sivakumar (2017), and McFerran et al. (2014) with a Likert scale of 1 for strongly disagree to 7 for strongly agree. Third, possession envy consisted of three items adopted from Sokolova and Kefi (2020), Horvath and Adiguzel (2018), and Greenwood et al. (2008) with a Likert scale of 1 for strongly disagrees to 7 for strongly agrees. Finally, purchase intention consisted of two items adopted from Centeno and Wang (2017) and Holmes and Redmond (2014) with a Likert scale of 1 for strongly disagree to 7 for strongly agree.

Table 2

Survey Instruments, Factor Loadings, CRs

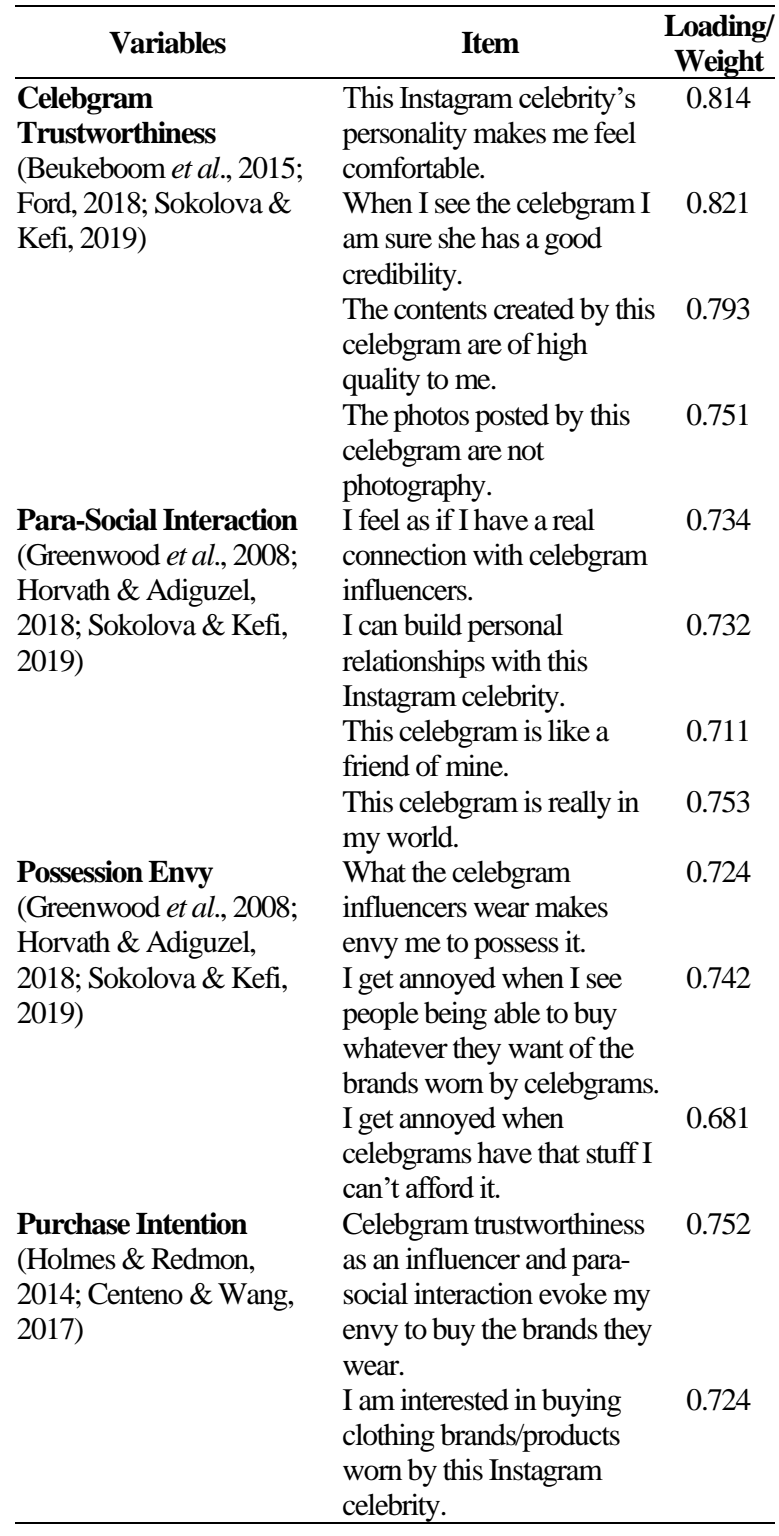

\section{Technique of Analysis}

The present study examined the proposed model by using two-stage Partial Least Squares (PLS) which allows to analyze the causality of the relationships among latent constructs (Hair, Ringle, \& Sarstedt, 2011). 


\section{Result and Discussion}

\section{Confirmatory Factor Analysis}

According to Anderson and Gerbing (1988), there were two stages of analysis to test a structural model: first, testing the overall fit of the hypothesized model. Based on the results of the model fit analysis, all of them are acceptable, with a goodness-of-fit-index (GFI) of 0.946, a comparative fit index (CFI) of 0.917, no standard residual of more than 2.000 , and a Chisquare of $616,322(100 d f, p=0.000)$, meaning that the overall fit of the model is acceptable (Hair et al., 2011). Second, the test of the adequacy of each scale consisting of statement items shows a significant standard in terms of convergent validity. Subsequently, the test of the adequacy of each scale consisting of the number of statement items covering each construct is shown in Table 3.

Each construct has a reliability of more than 0.761, thereby showing internal consistency. In addition, the Average Variance Extracted (AVE) ranges from 0.761 to 0.872 , indicating that the construct is larger than the variance caused by measurement error (Fornell \& Larcker, 1981).

Lastly, the Common Method Variance (CMV) was tested of the data. There are two approaches to testing CMV. First, the single factor commonly used was tested. The results showed that there was no single factor explaining the substantial portion of the total variance of the data. Subsequently, the general method factor was tested, showing that the method variance was very small relative to the substantive variance (the ratio being 57:1). The small method variance indicates that CMV was not a major problem in the data.

\section{Structural Models and Hypothesis Testing}

After confirming adequate data validity and reliability, the proposed research model was tested, showing that the measurement of the proposed model was in accordance with the data. Results of the analysis showed that celebgram trustworthiness had no effect on possession envy (Hypothesis 1).

Results of hypothesis testing shows that there is one insignificant latent construct, so that Hypothesis 1 is not supported. The other four latent constructs have a significant effect on purchase intention. Hypotheses 2 to 5 are proven; thus, they are supported, see Figure 2. Para-social interaction had an effect on possession envy (Hypothesis 2). Celebgram trustworthiness had an effect on purchase intention (Hypothesis 3). Possession envy had an effect on purchase intention (Hypothesis 4).

Table 4

Hypothesis Testing

\begin{tabular}{|c|c|c|c|c|}
\hline & Structural path & $\begin{array}{c}\text { Standardized } \\
\text { Estimate }\end{array}$ & $t$-statistic & $p$-values \\
\hline$\overline{H_{l}}$ & $\begin{array}{l}\text { Celebgram } \\
\text { trustworthiness - } \\
\text { possession envy }\end{array}$ & 0.372 & 7.625 & $0.075^{*}$ \\
\hline$H_{2}$ & $\begin{array}{l}\text { Para-social interaction } \\
\text { - possession envy }\end{array}$ & 0.571 & 6.115 & $0.001 * *$ \\
\hline $\mathrm{H}_{3}$ & $\begin{array}{l}\text { Celebgram } \\
\text { trustworthiness - } \\
\text { purchase intention }\end{array}$ & 0.162 & 9.721 & $0.002 * *$ \\
\hline $\mathrm{H}_{4}$ & $\begin{array}{l}\text { Social interaction - } \\
\text { purchase intention. }\end{array}$ & 0.274 & 11.476 & $0.001 * *$ \\
\hline $\mathrm{H}_{5}$ & $\begin{array}{l}\text { Possession envy-- } \\
\text { purchase intention. }\end{array}$ & 0.438 & 21.211 & $0.001 * *$ \\
\hline
\end{tabular}

Table 3

\section{CFA Correlation Matrix (Fornell-Larcker Criterion)}

\begin{tabular}{|c|c|c|c|c|}
\hline & Celebgram Trustworthiness & Para-Social Interaction & Possession Envy & Purchase Intention \\
\hline Celebgram trustworthiness & 0.813 & & & \\
\hline Para-Social Interaction & 0.251 & 0.872 & & \\
\hline Possession envy & -0.031 & 0.113 & 0.784 & \\
\hline Purchase Intention & 0.212 & 0.121 & 0.021 & 0.761 \\
\hline Age & 0.047 & 0.123 & 0.112 & 0.132 \\
\hline Gender & -0.062 & -0.014 & -0.011 & -0.011 \\
\hline Education & -0.046 & -0.054 & -0.021 & -0.211 \\
\hline Marital status & -0.037 & -0.036 & 0.021 & -0.012 \\
\hline Experience & 0.078 & 0.423 & 0.243 & -0.721 \\
\hline Composite Reliability (CR) & 0.947 & 0.921 & 0.652 & 0.732 \\
\hline Average Variance Extracted (AVE) & 0.328 & 0.477 & 0.765 & 0.124 \\
\hline Mean & 0.453 & 0.344 & 0.876 & 0.432 \\
\hline Standard Deviation (SD) & 0.244 & 0.081 & 0.043 & 0.021 \\
\hline
\end{tabular}

Model fit: $\chi^{2}=2.145, p<0.010$

${ }^{a}$ The square roots of $A V E$ for each construct are presented in bold on the diagonal of the correlation matrix.

${ }^{b}$ AVEs of formative indicators are not applicable.

${ }^{c}$ Note. $N=181$. 
Finally, possession envy had an effect on purchase intention (Hypothesis 5). Results of hypothesis testing are shown in Table 4 and Figure 2.

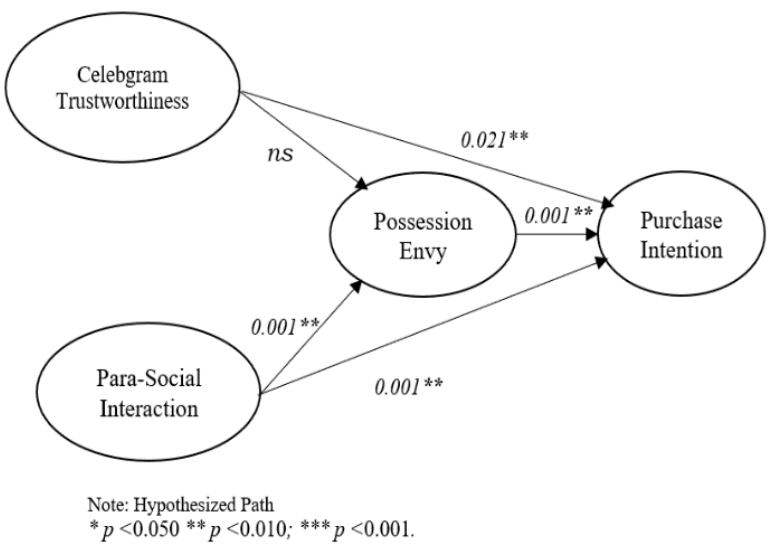

Figure 2. Results of the proposed model

\section{Discussion}

Results of the present study enrich the empirical findings regarding the effect of celebgram trustworthiness and para-social interactions on possession envy that need to be considered in influencer marketing on social media to increase consumer purchase intention. One important finding of the study is that celebgram trustworthiness originated from authority, credibility and social attractiveness has no effect on the emotion of consumer possession envy. This is due to the fact that the followers' emotions remain in the stage of searching for information about the celebgrams, whether they can be good influencers or not (for example, whether their followers are numerous or not, whether their followers are genuine or fake, whether the contents are good or not). At this stage, consumers are exploring, so that they still have no emotional ties to evoke envy (Milovic, 2014). Recalling the famous name of a celebgram does not guarantee satisfaction with a brand, even less those not well-known celebgrams (Jin \& Ryu, 2020). There is one question: Can an unknown celebgram showcasing a famous brand or, vice versa, a famous celebgram showcasing an unknown brand complement each other to influence followers? It is this question that constitutes the reason that celebgram trustworthiness cannot evoke the followers' possession envy. However, celebgram trustworthiness can be an important predictor in terms of increasing consumer purchase intention, given that celebgrams have a strong authority and social appeal to influence their followers (Chung \& Cho, 2017).

Parasoscial interaction plays an important role in increasing followers' emotions to possess the products and brands the celebgrams wear. Celebgrams post various photos, either selfies or taken by other people, and group photos, which show themselves wearing endorsed products in various styles, both in the photo catalog and directly on their YouTube account. When their followers are exposed to various photo poses posted by the celebgrams, the tendency to make social comparisons is higher, capable of triggering the followers' emotions to possess what their celebgrams showcase (Wiedemann et al., 2009; Lin, 2018). This is because followers' envy with instafamous-based materialistic values can drive consumers to make social comparisons with their idols (McFerran et al., 2014; Kim et al., 2015). The results of the present study also indicate that intimate social interactions can lead to compulsive buying. The higher the envy the higher consumer purchase intention is. This positive relationship is built from various photo posts, both selfies and in groups (Ajitha \& Sivakumar, 2017). In addition, possession envy is a strong predictor of consumer purchase intention. The relationship between possession envy and consumer purchase intention describes the competitive behavior of fellow consumers (Buunk \& Massar, 2012), which evokes the intention to buy a product caused by the envy.

\section{Conclusions and Implications}

The results of the present study provide theoretical foundations and managerial guidelines for ecommerce and social media marketing strategies via various interaction mechanisms and celebgram trustworthiness in evoking emotions and increasing purchase intention. There is an important finding that celebgram trustworthiness does not evoke followers' envy, despite the effect on consumer purchase intention. On the contrary, interaction with followers constitutes a catalyst in building consumer emotions in increasing purchase intention.

\section{Theoretical Implications}

The results of the present study provide theoretical contributions to retailing and consumer service and offer theoretical elucidation for Instafamous management-based marketing strategies. First, it corroborates the social comparison theory related to emotions or envy in terms of possession, which goes far beyond the existing literature, where the relationship between possession envy and consumer purchase intention is only illustrated by the status of celebrities who are well known via mainstream media (Lin, 2018). Second, this study corroborates PSI theory in terms of celebgram trustworthiness, which derives from celebgrams' 
personal credibility and social attractiveness via photo posts with various types of poses, both selfies and in groups.

\section{Managerial Implications}

The present study offers a new insight for marketers into social media which is useful for developing brand management strategies in the context of instafamous-based marketing. Marketers need to strategically select celebrities, both women and men, who are trustworthy as active supporters to form PSI with consumers who have considered the celebgram as their own friends, so as to increase purchase intention of the endorsed products. When this interaction occurs emotionally, possession envy would be evoked and in the end capable of increasing consumer purchase intention. Instafamous-based marketing allows companies to develop closer relationships through continuous brand communication which in turn can increase sales and customer loyalty (Xiang, Zheng, Lee, \& Zhao, 2016). The present study empirically corroborates the perceived celebgram trustworthiness through the quality of contents and content creators who are able to interact with consumers in influencing purchase intention.

\section{Limitation and Further Research}

First, marketing in the digital era that utilizes social media makes consumers more active and interactive with marketers (Hanna, Rohm, \& Crittenden, 2011). Given that there are so many brand variants and an increasingly diverse marketplace, it is necessary to undertake more in- depth studies related to consumer engagement (Dessart, Veloutsou, \& Morgan-Thomas, 2015) by (1) using experimental designs with regard to source credibility with experimental types of photos, both selfies and in groups; (2) using gender moderation variables to determine the differences in possession envy between men and women when looking at celebgram influencers; (3) studies are required regarding the correlation of wellknown brands to new celebgrams or well-known celebgrams to new brands. Thus, an effective engagement strategy will be found in using celebgrams as influencers (Men \& Tsai, 2016). Second, given that marketing on social media e-WOM is a strong antecedent to consumer purchase intention (Wang \& Yu, 2017), studies are required regarding celebgram popularity (i.e., number of followers) and brand popularity (i.e., number of likes and comments), peer content analysis, and product reviews. Thus, various comments from Instagram and e-WoM users will provide deeper insight into the role of celebgrams and brand popularity in interactions on e-commerce.

\section{References}

Abidin, C. (2016). Visibility labour: Engaging with influencers' fashion brands and \#ootd advertorial campaigns on instagram. Media International Australia, 161(1), 86-100. https://doi.org/10. $1177 \% 2 F 1329878 X 16665177$

Adler, R (2016). The 19 most sought-after Instagram beauty influencers of 2016. Retrieved from June 12, 2020 https://fashionista.com/ 2016/12/instagram-beauty-makeup-influenc ers-2016.

Ajitha, S., \& Sivakumar, V. J. (2017). Understanding the effect of personal and social value on attitude and usage behavior of luxury cosmetic brands. Journal Retailing and Consumer Services, 39, 103-113. https://doi.org/10.1016/j.jretconser. 2017.07.009

Anderson, J. C., \& Gerbing, D. W. (1988). Structural equation modeling in practice: A review and recommended two-step approach. Psychology Bulletin, 103(3), 411-423. https://doi.org/10.1037/ 00332909.103.3.411

AnyMind (2020). State of influencer marketing in Asia 2020 report. Retrieved March 2, 2020 from https://anymindgroup.com/news/announcement/ $7784 /$.

Arora, A., Bansal, S., Kandpal, C., Aswani, R., \& Dwivedi, Y. (2019). Measuring social media influencer index-insights from Facebook, Twitter and Instagram. Journal Retailing Consumer Service, 49, 86-101. https://doi.org/10.1016/j. jretconser.2019.03.012

Ashley, C., \& Tuten, T. (2015). Creative strategies in social media marketing: An exploratory study of branded social content and consumer engagement. Psychology Marketing, 32(1), 15-27. https://doi.org/10.1002/mar. 20761

Bandura, A. (2009). Social cognitive theory of mass communication. In J. Bryant, \& M. B. Oliver (Eds.), Media effects: Advances in Theory and Research, (2 ${ }^{\text {nd }}$ Ed., pp. 61-90). Mahwah, NJ: Lawrencec Erlbaum.

Barcelos, R. H., Dantas, D. C., \& Senecal, S. (2018). Watch your tone: How a brand's tone of voice on social media influences consumer responses. Journal of Interactive Marketing, 41, 60-80. https://doi.org/10.1016/j.intmar.2 017.10.001

Belk, R. W. (1984). Three scales to measure constructs related to materialism: Reliability, validity, and relationships to measures of happiness. NAAdvances in Consumer Research, 11, 291-297. (2008). Marketing and envy. In R. Smith (Ed.), Envy: Theory and research, 211-226. DOI:10. 1093/acprof:oso/9780195327953.0 03.0012. 
Beukeboom, C. J., Kerkhof, P., \& de Vries, M. (2015). Does a virtual like cause actual liking? How following a brand's Facebook updates enhances brand evaluations and purchase intention. Journal Interactive Marketing, 32, 26-36. http://dx.doi.org/10.1016/j.intm ar.2015.09.003

Boon, S., (2001). Admirer celebrity relationships among young adults. Explaining perceptions of celebrity influence on identity. Human Coтmunication Research, 27(3), 432-465. https://doi. org/10.1111/j.1468-2958.2001.tb 00788.x

Buunk, A. P., \& Massar, K., (2012). Intrasexual competition among males: Competitive towards men, prosocial towards women. Personality of Individual Differences, 52, 818-821. http://dx.doi. org/10.1016/j.paid.2012.01.01 0

Centeno, D., \& Wang, J. J. (2017). Celebrities as human brands: An inquiry on stakeholder actor cocreation of brand identities. Journal Business Research, 74, 133-138. https://doi.org/10.1016/ j.jbusres.2016.10.024

Chae, J. (2018). Explaining females' envy toward social media influencers. Media Psychology, 21(2), 246-262. https://doi.org/10.1080/152 13269.2017.1328312

Chaiken, S., (1979). Communicator physical attractiveness and persuasion. Journal of Personality and Social Psychology, 37(8), 1387-1397. https://doi.org/10.1037/0022-3514.37. 8.1387

Chung, S., \& Cho, H. (2017). Fostering parasocial relationships with celebrities on social media: Implications for celebrity endorsement. Psychology \& Marketing, 34(4), 481-495. https://doi. org/10.1002/mar.21001

Cooper, D. R., \& Schindler, P. (2013). Business research methods. $12^{\text {th }}$ Ed. USA: McGraw-Hill Education.

Dessart, L., Veloutsou, C., \& Morgan-Thomas, A. (2015). Consumer engagement in online brand communities: A social media perspective. Journal of Product and Brand Management, 24(1), 28-42. http://dx.doi.org/10.1108/JPBM-062014-0635

de Veirman, M., Cauberghe, V., \& Hudders, L. (2017). Marketing through Instagram influencers: The impact of number of followers and product divergence on brand attitude. International Journal Advertising, 36(5), 798-828. https://doi.org/10. 1080/02650487.2017. 1348035

de Vries, L., Gensler, S., \& Leeflang, P. S. (2012). Popularity of brand posts on brand fan pages: An investigation of the effects of social media marketing. Journal Interactive Marketing, 26(2), 83-91. https://doi.org/10.1016/j.intmar.2012.01. 003.
Dibble, J. L., Hartmann, T., \& Rosaen, S. F. (2015). Parasocial interaction and parasocial relationship: Conceptual clarification and a critical assessment of measures. Human Communication Research, 42(1), 21-44. https://doi.org/10.1111/hcre.12063

Djafarova, E., \& Rushworth, C. (2017). Exploring the credibility of online celebrities' in stagram profiles in influencing the purchase decisions of young female users. Computers in Human Behavior 68, 1-7. http://dx.doi.org/10.1016/ j.chb.2016.11.009

Ford, J. B. (2018). What do we know about celebrity endorsement in advertising? Journal Advertising Research, 58(1), 1-2. https:// doi.org/10.2501/ JAR-2018-006

Fornell, C., \& Larcker, D. F. (1981). Evaluating structural equation models with unobservable variables and measurement error. Journal Marketing Research, 18(1), 39-50. https://doi.org/10. 2307/3151312

Gallagher, C. E., Watt, M. C., Weaver, A. D., \& Murphy, K. A. (2017). I fear, therefore, I shop! Exploring anxiety sensitivity in relation to compulsive buying. Personality Individual Differerences, 104, 37-42. http://dx.doi.org/10.1016\% 2Fj.paid.2016.07.023

Gass, R. H. (2015). Social influence, sociology of. In J. Wright (Ed.), International Encyclopedia of the Social \& Behavioral Sciences (Second Edition, pp. 348-354). Elsevier.

Greenwood, D. N., Pietromonaco, P. R., \& Long, C. R. (2008). Young women's attachment style and interpersonal engagement with female tv stars. Journal of Social and Personal Relationships, 25(3), 387-407. https://doi.org/10.1177/026540 7507087964

Gunawan, D. D., \& Huarng, K. H. (2015). Viral effects of social network and media on con sumers' purchase intention. Journal Business Research, 68, 2237-2241. http://dx.doi.org/10.1016/j.jbusres.2015.06.004

Hagtvedt, H., \& Patrick, V. M. (2009). The broad embrace of luxury: Hedonic potential drive of brand extendibility. Journal Consumer Psychology, 19(4), 608-618. https://doi.org/10.1016/j. jcps.2009.05.007

Hair, J. F., Ringle, C. M., \& Sarstedt, M. (2011). PLSSEM: Indeed a silver bullet. Journal Marketing Theory and Practice, 19(2), 139-152. https://doi. org/10.2753/MTP10696679 190202

Hanna, R., Rohm, A. J., \& Crittenden, V. L. (2011). We're all connected: The power of the social media ecosystem. Business Horizons, 54, 265373. http://dx.doi.org/10.1016/j.bushor.2011.01. 007. 
Hautz, J., Füller, J., Hutter, K., \& Thürridl, C. (2014). Let users generate your video ads? The impact of video source and quality on consumers' perceptions and intended behaviors. Journal Interactive Marketing, 28(1), 1-15. https://doi.org/10.1016/ j.intmar.2013.06. 003

Holmes, S., \& Redmond, S. (2014). Socialising celebrity. Celebrity studies, 5(3), 223-224. https://doi. org/10.1080/19392397.2014.935631

Horton, D., \& Wohl, R. R. (1956). Mass communication and para-social interaction: Observations on intimacy at a distance. Psychiatry, 19(3), 215229. https://doi.org/10.1080/00332747.1956. 11023049

Horvath, C., \& Adiguzel, F. (2018). Shopping enjoyment to the extreme: Hedonic shopping motivations and compulsive buying in developed and emerging markets. Journal of Business Research, 86, 300-310. https://doi.org/10.1016/ j.jbusres.2017.07.013

Hwang, K., \& Zhang, Q., (2018). Influence of parasocial relationship between digital celebrities and their followers on followers' purchase and electronic word of mouth intentions, and persuasion knowledge. Computers in Human Behavior, 87, 155-173. https://doi.org/10.1016/j.chb.2018.05. 029

Indvik, L. (2016). The 20 most influential personal style bloggers: 2016 Edition. Retrieved from June 12, 2020. https://fashionista.com/ 2016/03/stylebloggers-2016.

Islam, T., Sheikh, Z., Hameed, Z., Khan, I. U., \& Azam, R. I. (2018). Social comparison, materialism, and compulsive buying based on stimulus-response-model: A comparative study among adolescents and young adults. Young Consumers, 19(1), 19-37. https://doi.org/10.1108/ YC-07-2017-00713

Jin, S. V., \& Muqaddam, A. (2018). Narcissism 2.0! Would narcissists follow fellow narcissists on lnstagram? The mediating effect of narcissists personality similarity and envy and the moderating effects of popularity. Computers in Human Behavior, 81,31-41. https://doi.org/10.1016/ j.chb.2017.11.04 2

Jin, S. V., Muqaddam, A., \& Ryu, E. (2019). Instafamous and social media influencer marketing. Marketing Inteligence \& Planning, 37(5), 567579. https://doi.org/10.1108/MI P-09-2018-0375

Jin, S. V, \& Ryu, E. (2020). I'll buy what she's \#wearing": The roles of envy toward and parasocial interaction with influencers in Instagram celebritybased brand endorsement and social commerce. Journal of Retailing and Consumer Services, 55, 102121. https://doi.org/10.1016/j. jretconser.2020.102121

Jin, S. V., Ryu, E., \& Muqaddam, A. (2018). Dieting 2.0! Moderating effects of instagrammers' body image and instafame on other instagrammers' dieting intention. Computers in Human Behavior, 87, 224-237. https://doi.org/10.1016/j.chb.2018. 06.001

Kelleher, T. (2009). Conversational voice, communicated commitment, and public relations outcomes in interactive online communication. Journal of Communication, 59(1), 172-188. https://doi.org/10.1111/j.1460-2466.2008.0 1410.x

Kelleher, T., \& Miller, B. M. (2006). Organizational blogs and the human voice: Relational strategies and relational outcomes. Journal of ComputerMediated Communication, 11(2), 395-414. https://doi.org/10.1111/j.1083 6101.2006.00019.x

Kelman, H., (1958). Compliance, identification, and internalization: Three processes of attitude change. Journal of Conflict Resolution, 2(1), 5160. https://doi.org/10.1177/2F00220027580020 0106

Kim, A. J., \& Johnson, K. K. P. (2016). Power of consumers using social media: Examining the influences of brand related user-generated content on Facebook. Computer in Human Behavior, 58, 98-108. http://dx.doi.org/10.1016/j.chb. 2015.12.047

Kim, H., Ko, E., \& Kim, J. (2015). SNS users' parasocial relationships with celebrities: Social media effects on purchase intentions. Journal of Global Scholars of Marketing Science, 25(3), 279-294. https://doi.org/10.1080/ 21639159.2015.1043690

Labrecque, L. I. (2014). Fostering consumer - Brand relationships in social media environments: The role of parasocial interaction. Journal Interacting Marketing, 28(2), 134-148. http://dx.doi.org/10. 1016/j.intmar.2013.12.003

Lee, J. E., \& Watkins, B. (2016). YouTube vloggers' influence on consumer luxury brand perceptions and intentions. Journal of Business Research, 69, 5753-5760. http://dx.doi.org/10.1016/j.jbusres. 2016.04.171

Lin, R. (2018). Silver lining of envy on social media? The relationships between post content, envy type, and purchase intentions. Internet Research, 28(4), 1142-1164. https://doi.org/ 10.1108/IntR05-2017-0203

Loureiro, S. M. C., Costa, I., \& Panchapakesan, P. (2017). A passion for fashion: the impact of social influence, vanity, and exhibitionism on consumer 
behavior. International Journal Retailing Distribution Management, 45(5), 468-484. https://doi. org/10.1108/IJRDM-11-2016-0202

McFerran, B., Aquino, K., \& Tracy, J. L. (2014). Evidence for two facets of pride in consumption: Findings from luxury brands. Journal Consumer Psychologic, 24, 455-471. https://doi.org/10.1016/ j.jcps.2014.03.004

Men, L. R., \& Tsai, W. (2016). Public engagement with CEOs on social media: Motivations and relational outcomes. Public Relations Review, 42(5), 932-942. https://doi.org/10.1016/j.pubrev. 2016.08.001

McCroskey, J. C., \& Teven, J. J. (1999). Goodwill: A reexamination of the construct and its measurement. Communication Monographs, 66(1), 90103. https://doi.org/10.1080/03637759909376464

Milovic, A. J. (2014). "If you have It, I want it...now!" The effect of envy and construal level on increased purchase intentions. Theses and Dissertations. University of Wisconsin Milwaukee.

Muller, J., \& Christandl, F. (2019). Content is the king but who is the king of kings? The effect of content marketing, sponsored content and user-generated content on brand responses. Computer in Human Behavior, 96, 46-55. http://dx.doi.org/10.1016/ J.CHB.2019.02.006

Müller, L., Mattke, J., \& Maier, C. (2018). \#Sponsored \#Ad: Exploring the effect of influencer marketing on purchase intention. Proceedings: Twentyfourth Americas Conference on Information Systems, New Orleans, 2018.

Nambisan, P., \& Watt, J. H. (2011). Managing customer experiences in online product communities. Journal of Business Research, 64 (8), 889-895. https://doi.org/10.1016/j.jbus res. 2010.09.006

Peter, J. P., \& Olson, J. C. (2004). Consumer behavior and marketing strategy. $7^{\text {th }}$ Edition. USA: McGraw-Hill (Tx).

Petty, R. E., \& Wegener, D. T. (1998). Matching versus mismatching attitude functions: Implications for scrutiny of persuasive messages. Personality Social Psychology Bulletin, 24(3), 227-240. https://doi.org/10.1177/014616729824 3001.

Pratnyawan, A., \& Prisilia, A. (2018). 5 selebgram muda Indonesia ini terkenal dengan bisnisnya. Retrieved from June 12, 2020 https://www. hitekno.com/internet/2018/08/06/170000/5selebgram-muda-indonesia-ini-terkenal-denganbisnisnya.

Purwanto \& Kuswandi. (2017). Effects of flexibility and interactivity on the perceived value of and satisfaction with e-commerce (Evidence from Indonesia). Market-Tržište, 29(2), 139-159. https://doi.org/10.22598/mt/2017. 29.2.139
Ridgway, N., Kukar-Kinney, M., \& Monroe, K.B. (2008). An extended conceptualization and measure of compulsive buying. Journal of Consumer Research, 35(4), 622-639. https://doi.org/10. $1086 / 591108$

Rogers, E. M., \& Bhowmik, D. K. (1970). Homophilyheterophily: Relational concepts for communication research. Public Opinion Quarterly, 34(4), 523-538. https://doi.org/ 10.1086/267838

Roma, P., \& Aloini, D. (2019). How does brand related user generated content differ across social media? Evidence reloaded. Journal of Business Research, 96, 322-339. http://dx.doi.org/10.1016/j.jbusres. 2018.11.055

Schulze, C., Scholer, L., \& Skiera, B. (2015). Customizing social media marketing. MIT Sloan Management Review, 56, 7-10.

Sharma, A., (1990). The persuasive effect of salesperson credibility: Conceptual and empirical examination. Journal of Personal Selling and Sales Management, 10(4), 71-80. https://doi.org/ 10.1080/08853134.1990.10753850

Sokolova, K., \& Kefi, H. (2020). Instagram and YouTube bloggers promote it, why should I buy? How credibility and parasocial interaction influence purchase intentions. Journal Retailing Consumer Services, 53, 101742. https://doi.org/ 10.1016/j.jretconser.2019.01.011

Sukhdial, A., Aiken, D., \& Kahle, L. (2002). Are you old school? A scale for measuring sports fans' old-school orientation. Journal Advertising Research, 42(4), 71-81.

Wang, Y., \& Yu, C. (2017). Social interaction-based consumer decision-making model in social commerce: The role of word of mouth and observational learning. International Journal of Information Management, 37(3), 179-189. http://dx.doi.org/10.1016/j.ijinfom gt.2015.11.005

Wiedemann, K. P., Hennigs, N., \& Siebels, A. (2009). Value-based segmentation of luxury consumption behavior. Psychology and Marketing, 26(7), 625-651. http://dx.doi.org/10.10 02/mar.20292

Xiang, L., Zheng, X., Lee, M. K. O., \& Zhao, D. (2016). Exploring consumers' impulse buying behavior on social commerce platform: The role of parasocial interaction. International Journal Information Management, 36, 333-347. https://doi.org/10.1016/j.ijinfomgt .2015.11.002

Yoo, W. S., Lee, Y., \& Park, J. K. (2010). The role of interactivity in e-tailing: Creating value and increasing satisfaction. Journal of Retailing and Consumer Services, 17(2), 89-96. https://doi.org/ 10.1016/j.jretconser.2009.10.003. 